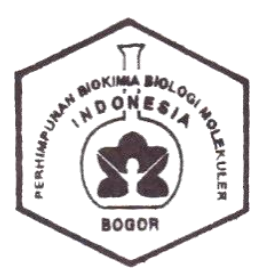

CURRENT BIOCHEMISTRY

ISSN: $2355-7877$

e-ISSN: 2355-7931

Journal homepage: http://journal.ipb.ac.id/index.php/cbj

Journal E-mail: current.biochemistry@gmail.com

\title{
Analysis of Blood Hemoglobin Levels Using Biosensors Based on Heme Oxygenase from Serratia marcescens
}

(Analisis Kadar Hemoglobin Darah Menggunakan Biosensor Berbasis Heme Oksigenase dari Serratia marcescens)

\author{
Ahmad Irvan Pratama ${ }^{1}$, Aisyah Sahara ${ }^{2}$, Sintia Intan Agsari ${ }^{1}$ \\ ${ }^{1}$ Departemen Biokimia, IPB University, Bogor, 16680, Indonesia \\ ${ }^{2}$ Department Biologi, IPB University, Bogor, 16680, Indonesia
}

Received: 22 August 2019; Accepted: 27 May 2020

Corresponding author : Ahmad Irvan Pratama, Departemen Biokimia, IPB University;

Email: irvanpratama97@gmail.com

\begin{abstract}
Hemoglobin levels are influenced by nutrition, iron conditions, and body metabolism. One of the medical disorders related to human blood, especially erythrocyte levels is anemia. This condition causes the need for effective and efficient methods of measuring blood hemoglobin levels, including in terms of cost. One alternative measurement of hemoglobin levels that can be used is the heme oxygenase-based sensor from Serratia marcescens. This study aims to develop techniques to measure blood hemoglobin levels by utilizing biological sensor based on heme oxygenase from Serratia marcescens. The stages of the experiments include: rejuvenation and production of Serratia marcescens isolates, isolation of heme oxygenase, purification of enzymes with ammonium sulphate 45-65\% and 65-85\% saturation, measurement of protein content and enzyme activity, enzyme immobilization to the surface of carbon electrodes, and assay of biosensor heme oxygenase kinetics. Test of protein content and enzyme activity produces enzyme specific activity at 45-65\% fraction of $0.0158 \mathrm{U} / \mathrm{mg}$ and at $65-85 \%$ fraction of $0.0069 \mathrm{U} / \mathrm{mg}$, so the fraction to be used in biosensors is 45-65\% fraction. The biosensor kinetics test results in a hemoglobin level of 12.0, 13.8 , and $14.3 \mathrm{~g} / \mathrm{dL}$ in blood samples $A, B$, and, $C$, while the hemoglobin level measured in a standard laboratory test is 12.0, 13.8, and $14.3 \mathrm{~g} / \mathrm{dL}$. It was concluded that the biosensors developed in this study can measure hemoglobin levels in blood samples with a precision of 0.8 and an accuracy of $96.04 \%$.
\end{abstract}

Keywords: Biosensor, Heme Oxygenase, Hemoglobin, Serratia marcescens 


\begin{abstract}
ABSTRAK
Kadar hemoglobin pada manusia dipengaruhi oleh gizi, kondisi zat besi dan metabolisme dalam tubuh. Salah satu gangguan medis terkait darah manusia khususnya kadar eritrosit adalah anemia. Kondisi ini menyebabkan perlunya metode pengukuran kadar hemoglobin darah yang efektif dan efisien termasuk dari segi biaya. Salah satu alternatif pengukuran kadar hemoglobin yang dapat digunakan adalah dengan sensor berbasis heme oksigenase dari Serratia marcescens Penelitian ini bertujuan mengembangkan teknik pengukuran kadar hemoglobin darah dengan memanfaatkan sensor hayati berbasis enzim heme oksigenase dari Serratia marcescens. Tahapan yang dilalui pada penelitian ini adalah peremajaan dan produksi isolat Serratia marcescens, isolasi heme oksigenase, pemurnian parsial enzim dengan larutan yang mengandung 45-65\% dan 65-85\% amonium sulfat jenuh, pengukuran kadar protein dengan metode Bradford dan aktivitas enzim, amobilisasi enzim ke permukaan Screen Printed Carbon Electrode (SPCE), dan uji kinetika biosensor heme oksigenase. Uji kadar protein dan aktivitas enzim menghasilkan aktivitas spesifik enzim pada fraksi 45-65\% sebesar 0.0158 U/mg dan pada fraksi $65-85 \%$ sebesar $0.0069 \mathrm{U} / \mathrm{mg}$, sehingga fraksi yang digunakan pada biosensor adalah fraksi 45-65\%. Uji kinetika biosensor menghasilkan kadar hemoglobin sebesar 12.0, 13.8, dan $14.3 \mathrm{~g} / \mathrm{dL}$ pada sampel darah A, B, dan C, sedangkan hasil pengukuran dengan uji laboratorium standar berturut-turut sebesar 13.2, 13.4, dan $14.2 \mathrm{~g} / \mathrm{dL}$. Kesimpulan yang didapatkan dari penelitian ini ialah biosensor yang telah dibuat dapat mengukur kadar hemoglobin pada darah sampel dengan presisi sebesar 0.8 dan akurasi $96.04 \%$.
\end{abstract}

Keywords: Biosensor, Heme Oksigenase, Hemoglobin, Serratia marcescens

\section{PENDAHULUAN}

Hemoglobin $(\mathrm{Hb})$ merupakan protein utama tubuh manusia yang membuat darah berwarna merah. Fungsi fisiologi hemoglobin ialah mengatur pertukaran oksigen dan karbondioksida, menyuplai nutrisi ke jaringan tubuh, membantu kestabilan tahanan tekanan terhadap aliran darah dalam pembuluh darah perifer, sehingga sirkulasi darah yang dipompa ke jantung dapat dipertahankan dari serangan virus dan bakteri patogen. Batas normal kadar hemoglobin untuk kelompok umur 6-14 tahun dan wanita dewasa ialah $12 \mathrm{~g} / 100 \mathrm{ml}$, untuk laki-laki dewasa $13 \mathrm{~g} / 100 \mathrm{ml}$, dan wanita hamil $11 \mathrm{~g} / 100 \mathrm{ml}$ (Katanga et al. 2015). Kadar $\mathrm{Hb}$ pada manusia ini dipengaruhi oleh gizi, kondisi besi, dan metabolisme dalam tubuh.

Anemia merupakan kondisi menurunnya kadar hemoglobin darah dalam tubuh. Kondisi ini memerlukan metode pengukuran kadar hemoglobin darah yang efektif, efisien, dan ekonomis. Metode pengukuran kadar hemoglobin secara laboratorium yang dapat digunakan salah satunya ialah metode cyanomethemoglobin. Metode ini dilakukan dengan memb; intensitas warna sampel dengan fotometer kemudian dibandingkan dengan standar. Metode ini memiliki kekurangan yaitu harga fotometer masih tergolong mahal jika diterapkan di Indonesia karena masih diimpor, sehingga belum semua laboratorium memilikinya (Rodak et al. 2012). Selain metode pengukuran secara laboratorium, saat ini telah dikembangkan alat pengukur kadar hemoglobin praktis dengan memanfaatkan prinsip reaksi elektrokimia dalam pembacaan kadar hemoglobin darah. Akan tetapi, pengadaan alat ukur tersebut masih dengan cara impor dan terbilang mahal, sehingga diperlukan alat yang merupakan produk buatan lokal tanpa impor dari negara lain.

Salah satu alternatif pengukuran kadar hemoglobin yang dapat digunakan dengan menggunakan sensor berbasis enzim yang didapatkan dari sumber-sumber lokal (indigenous). Sensor berbasis enzim 
merupakan jenis biosensor yang memanfaatkan reaksi elektrokimia dengan menggabungkan senyawa hayati dengan suatu tranduser (Evtugyn 2014). Menurut Evtugyn (2014), metode elektrokimia memiliki keunggulan dibandingkan metode spektrofotometri, yaitu lebih sensitif dalam mendeteksi sampel dalam jumlah sedikit. Selain itu, penelitian sebelumnya yang dilakukan oleh Koga et al. (2013) menggunakan enzim heme oksigenase yang diisolasi dari tikus dapat mendeteksi heme pada konsentrasi yang sangat kecil yaitu kurang dari $10 \mathrm{nM}$.

Penelitian ini bertujuan memanfaatkan enzim dalam pengembangan biosensor berbasis heme oksigenase dari bakteri hemolitik isolat lokal. Salah satu bakteri hemolitik yang dapat menghasilkan heme oksigenase ialah Serratia marcescens (Contreras et al. 2014). Serratia marcescens dipilih pada penelitian ini karena selain memiliki kemampuan menghasilkan heme oksigenase (kemampuan melisis darah), bakteri ini juga merupakan isolat yang tingkat patogenitasnya rendah.

\section{METODOLOGI}

Alat-alat yang digunakan pada penelitian ini yaitu seperangkat peralatan gelas, sentrifus, shaker, pengaduk magnetik, jarum ose, pengukur suhu, autoklaf, cawan petri, pengukur $\mathrm{pH}$, mortar, potensiostat eDAQ, Elektroda Pasta Karbon (EPK) dengan menggunakan Screen Printed Carbon Electrode (SPCE). Bahan-bahan yang digunakan pada penelitian ini yaitu media Luria Bertani (LB) bubuk, darah domba steril (pengambilan dan penyimpanan dalam kondisi steril) yang didapatkan dari Fakultas Kedokteran Hewan IPB, 2,2-Bipiridil $2 \mathrm{mM}$, $50 \mathrm{mM}$ bufer Tris-HCl pH 7.0, $1 \mathrm{mM}$ EDTA, isolat bakteri hemolitik yang didapat dari IPB Culture Collection, air deionisasi, larutan $\mathrm{NaOH} 0.2 \mathrm{~g} / \mathrm{mL}$, glutaraldehida $2.5 \%$, NADPH $\quad 0.1 \mathrm{mM}, \quad$ Phenylmethylsulfonyl
Fluoride (PMSF) $1 \mathrm{mM}$, dan biliverdin hidroklorida.

\section{Prosedur Penelitian \\ Peremajaan dan Perbanyakan Kultur Bakteri (modifikasi Karama et al. 2008)}

Media dan alat-alat gelas yang digunakan untuk peremajaan isolat disterilkan terlebih dahulu dengan menggunakan autoklaf pada suhu $121{ }^{\circ} \mathrm{C}$ dan tekanan $1 \mathrm{~atm}$. Media yang digunakan adalah media Luria Bertani (LB) darah cair (5 gram media LB bubuk, 5 $\mathrm{mL}$ darah domba steril) sebanyak $100 \mathrm{~mL}$ dengan penambahan 2,2-bipiridil, dan media agar darah (komposisi seperti media darah cair dengan tambahan 1.5 gram agar). Isolat bakteri dari agar miring diambil menggunakan jarum ose, kemudian digoreskan ke media agar darah. Isolat tersebut diinkubasi selama selama 24 jam pada suhu $37{ }^{\circ} \mathrm{C}$. Koloni bakteri dari cawan diambil dengan menggunakan jarum ose lalu dimasukkan ke dalam media LB darah cair dan diinkubasi selama 12 jam pada suhu $37{ }^{\circ} \mathrm{C}$ dengan menggunakan shaker. Tahap ini menghasilkan isolat bakteri dalam media cair darah yang ditandai perubahan warna media darah menjadi lebih gelap dan keruh.

\section{Pembuatan Kurva Pertumbuhan Serratia marcescens}

Kurva pertumbuhan S.marcescens dibuat dengan terlebih dahulu dilakukan pengambilan isolat seluas $1 \mathrm{~cm}^{2}$ dari diameter cawan dengan menggunakan jarum ose. Isolat tersebut kemudian dimasukkan ke dalam $5 \mathrm{~mL}$ media cair LB. Media yang telah berisi isolat tersebut diinkubasi pada suhu $37^{\circ} \mathrm{C}$ pada shaker incubator selama 24 jam. Selanjutnya, sebanyak $0.05 \mathrm{~mL}$ larutan yang berisi isolat bakteri tersebut dimasukkan ke dalam botol vial masing-masing sebanyak 10 buah lalu ditambahkan media cair LB steril hingga volume $5 \mathrm{~mL}$. Isolat dalam 10 botol vial tersebut lalu diinkubasi pada suhu $37^{\circ} \mathrm{C}$. Tahap selanjutnya adalah pengukuran densitas optik dengan menggunakan spektrofotometer $U V$ Visible dengan panjang gelombang $620 \mathrm{~nm}$ setiap 3 jam, dimulai pada jam ke-0 hingga 
absorbansi yang terbaca relatif tidak lagi mengalami kenaikan. Larutan blanko yang digunakan adalah media cair LB steril.

\section{Isolasi Heme Oksigenase (modifikasi Wilks dan Schmitt 1998)}

Isolat hasil inkubasi 24 jam pada suhu

$37{ }^{\circ} \mathrm{C}$ disentrifus dengan kecepatan $8000 \times \mathrm{g}$ selama 20 menit kemudian diambil peletnya. Pelet yang berisi sel bakteri kemudian dihancurkan dengan menggunakan sonikator dan penambahan $50 \mathrm{mM}$ bufer Tris $\mathrm{pH} 7.0,1$ mM PMSF, dan $1 \mathrm{mM}$ EDTA. Homogenat kemudian disentrifus dengan kecepatan 21000 $\mathrm{x}$ g selama 60 menit. Supernatan yang dihasilkan merupakan ekstrak kasar heme oksigenase.

\section{Pemurnian Parsial Heme Oksigenase dengan Fraksinasi Ammonium Sulfat (modifikasi Hammami et al. 2013)}

Pemurnian dilakukan dengan teknik pengendapan bertingkat menggunakan amonium sulfat. Ekstrak kasar enzim dimurnikan dengan penambahan amonium sulfat jenuh 45-65\%, dan $65-85 \%$. Penambahan amonium sulfat di setiap konsentrasi ditambahkan sedikit demi sedikit sambil diaduk menggunakan pengaduk magnetik pada suhu $4{ }^{\circ} \mathrm{C}$. Ekstrak kasar enzim kemudian dilakukan sentrifugasi dengan kecepatan 8000 x g selama 20 menit. Pelet yang didapat dari setiap tingkat pemurnian diresuspensi dengan $50 \mathrm{mM}$ bufer Tris $\mathrm{pH}$ 7.0, $1 \mathrm{mM}$ PMSF, dan $1 \mathrm{mM}$ EDTA kemudian diukur aktivitas dan kadar protein totalnya untuk mengetahui aktivitas optimumnya.

\section{Pengukuran Kadar Protein (modifikasi Cheng et al. 2016)}

Kadar protein diukur dengan mencampur sebanyak $0.05 \mathrm{~mL}$ sampel ekstrak enzim dengan $2.5 \mathrm{~mL}$ reagen Bradford lalu dihomogenkan dengan menggunakan vortex. Campuran kemudian diinkubasi selama 2 menit, kemudian diukur nilai absorbansinya dengan menggunakan spektrofotometer $U V$ Vis pada panjang gelombang $595 \mathrm{~nm}$. Larutan blanko yang digunakan adalah $2.5 \mathrm{~mL}$ reagen Bradford ditambahkan $0.05 \mathrm{~mL}$ bufer Tris 50 $\mathrm{mM}$ pH 7.0, PMSF $1 \mathrm{mM}$, dan EDTA $1 \mathrm{mM}$. Kurva standar protein dibuat dengan menggunakan larutan Bovine Serum Albumin (BSA) dengan konsentrasi 0.1-1.0 $\mathrm{mg} / \mathrm{mL}$. Persamaan garis kurva standar digunakan untuk menentukan kadar protein pada sampel.

\section{Uji Aktivitas Heme Oksigenase (Modifikasi Hammami et al. 2013)}

Aktivitas heme oksigenase diukur dengan memasukkan $0.1 \mathrm{~mL}$ ekstrak enzim ke dalam tabung reaksi yang berisi $1.5 \mathrm{~mL}$ larutan hemoglobin $0.5 \% \mathrm{~b} / \mathrm{v}$ dan NADPH $0.1 \mathrm{mM}$ lalu dihomogenkan menggunakan vortex. Larutan kemudian diinkubasi selama 5 menit. Setelah diinkubasi tepat 2 menit, larutan diukur nilai absorbansinya dengan menggunakan spektrofotometer $U V$-Vis pada panjang gelombang $663 \mathrm{~nm}$. Kurva standar heme oksigenase dibuat dengan menggunakan larutan biliverdin hidroklorida dengan konsentrasi $0.01-0.2 \mathrm{mg} / \mathrm{mL}$. Kontrol negatif yang digunakan pada pengukuran ini adalah larutan bufer $\mathrm{pH} 7.0$ sebanyak $5 \mathrm{~mL}$ yang dicampur dengan $1 \mathrm{~mL}$ ekstrak enzim.

\section{Amobilisasi Heme Oksigenase pada SPCE (modifikasi Evtugyn 2014; Kurniasih 2014)}

Sebanyak $10 \mu \mathrm{L}$ enzim heme oksigenase dari fraksi dengan aktivitas spesifik terbaik dicampur dengan $1 \mathrm{mg}$ BSA, $50 \mu \mathrm{L}$ bufer kalium fosfat $\mathrm{pH} 7.0$, dan $30 \mu \mathrm{L}$ glutaraldehida $2.5 \%$. Campuran tersebut kemudian dimasukkan ke dalam tabung mikro dan dikocok perlahan. Campuran lalu diteteskan ke atas permukaan SPCE sebanyak $10 \mu \mathrm{L}$. Heme oksigenase yang telah teramobil di permukaan elektroda tersebut dikeringkan pada suhu $4{ }^{\circ} \mathrm{C}$. Setelah elektroda kering, elektroda dicuci dengan menggunakan bufer kalium fosfat $\mathrm{pH} 7.0$ untuk menghilangkan enzim sisa yang tidak teramobil. Elektroda disimpan dalam lemari pendingin $4{ }^{\circ} \mathrm{C}$. 


\section{Penentuan Parameter Kinetika Biosensor Heme Oksigenase}

Parameter kinetika ditentukan dengan penentuan aktivitas enzim pada variasi konsentrasi hemoglobin dalam larutan bufer Tris- $\mathrm{HCl} \mathrm{pH}$ 7.0. Larutan hemoglobin dibuat menjadi beberapa konsentrasi yang berbeda yaitu $0.00 \%, 0.05 \%, 0.10 \%, 0.15 \%$, dan $0.20 \%$ (v/v). Masing-masing larutan hemoglobin tersebut kemudian diuji pengaruhnya terhadap aktivitas enzim heme oksigenase secara elektrokimia dengan menggunakan Biosensor teramobil Heme Oksigenase yang telah dibuat. Hasil pengukuran tersebut kemudian dibuat kurva standar hemoglobin untuk digunakan sebagai dasar penghitungan konsentrasi hemoglobin darah. Pengukuran kadar hemoglobin darah dilakukan dengan terlebih dahulu melakukan pengenceran darah sampel 100x yaitu dengan melarutkan darah sebanyak $0.1 \mathrm{~mL}$ ke dalam bufer Tris- $\mathrm{HCl} \mathrm{pH} 7.0$ sebanyak $9.9 \mathrm{~mL}$. Larutan darah tersebut kemudian diukur arus yang ditimbulkannya dengan menggunakan Biosensor yang telah dibuat. Nilai kuat arus yang dihasilkan kemudian dikonversi ke dalam nilai konsentrasi hemoglobin darah. Nilai kadar hemoglobin yang terukur kemudian dibandingkan dengan nilai kadar hemoglobin yang dilakukan dengan uji laboratorium standar.

\section{HASIL}

\section{Kurva Pertumbuhan Serratia marcescens}

Hasil yang didapatkan pada pembuatan kurva pertumbuhan bakteri Serratia marcescens menunjukkan fase pertumbuhan bakteri mulai dari fase lag, log, dan fase stationary. Fase lag berlangsung antara jam ke-0 hingga jam ke-3, fase log dimulai pada jam ke-3 hingga jam ke-18, dan fase stationary terjadi di atas jam ke-18 (Gambar 1). Berdasarkan kurva pertumbuhan tersebut, waktu inkubasi kultur sel yang optimum dimulai pada jam ke-18 karena kultur berada pada titik awal dari puncak jumlah biomassa selnya, sehingga jumlah heme oksigenase yang terdapat pada koloni bakteri berada pada puncaknya.

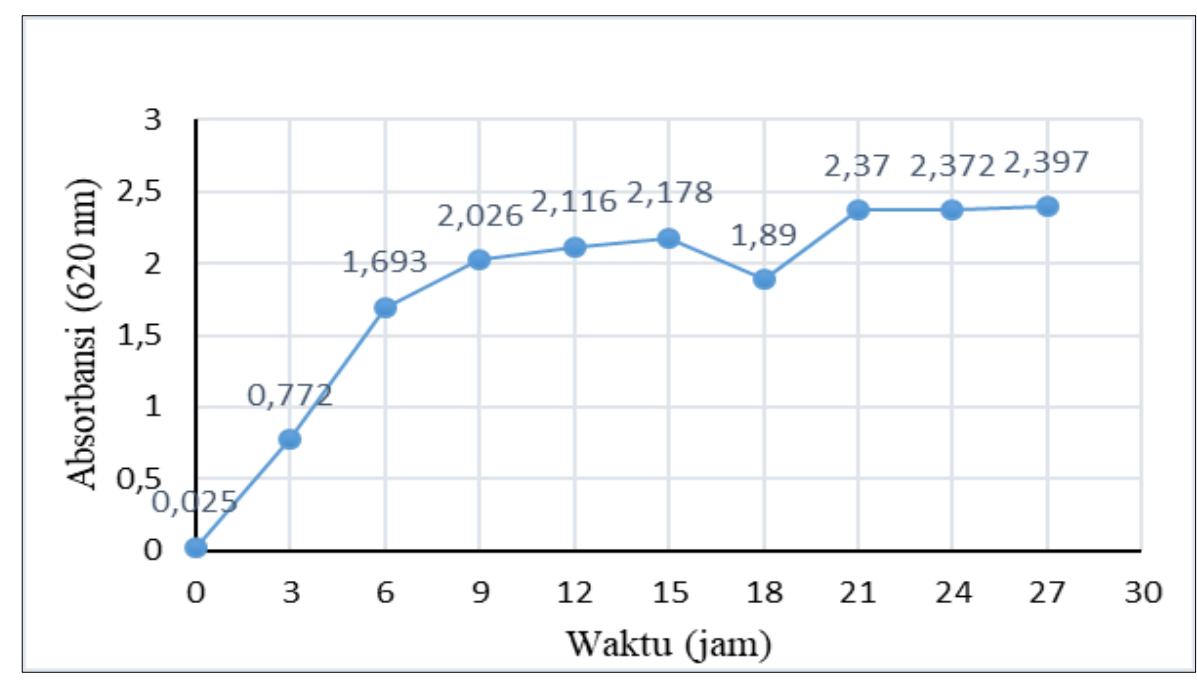

Gambar 1 Kurva Pertumbuhan Serratia marcescens 


\section{Heme Oksigenase Hasil Fraksinasi Amonium Sulfat}

Biomassa sel yang didapatkan dari kultivasi kultur bakteri pada jam ke 18 adalah sebanyak 1.6042 gram. Tahapan berikutnya setelah isolasi enzim adalah fraksinasi ekstrak kasar enzim. Fraksinasi heme oksigenase dilakukan dengan pengendapan bertingkat pada konsentrasi amonium sulfat $45-65 \%$ dan $65-85 \%$. Bobot endapan yang didapat pada fraksi $45-65 \%$ adalah 0.3788 gram, sedangkan bobot endapan pada fraksi $65-85 \%$ adalah 0.1874 gram (Tabel 1). Hasil fraksi yang didapatkan akan digunakan dalam pengukuran kadar protein dan uji aktivitas enzim pada tahap selanjutnya.

\section{Kadar Protein dan Aktivitas Heme Oksigenase}

Kadar protein diketahui dengan menentukan kurva standar protein dengan beberapa konsentrasi yang diketahui. Kurva standar protein dibuat dengan menggunakan larutan BSA dengan konsentrasi 0.0, 0.2, 0.4, $0.6,0.8$, dan $1.0 \mathrm{mg} / \mathrm{mL}$. Kadar protein sampel yang didapatkan dari fraksi $45-65 \%$ adalah sebesar $1.0725 \mathrm{mg} / \mathrm{mL}$, sedangkan kadar protein dari fraksi $65-85 \%$ adalah sebesar $0.9229 \mathrm{mg} / \mathrm{mL}$. Aktivitas enzim dapat diketahui melalui pengukuran konsentrasi biliverdin yang terbentuk dari hasil reaksi enzimatis. Kurva standar biliverdin dibuat dengan menggunakan larutan biliverdin konsentrasi $0.04,0.08,0.12,0.16$, dan 0.20 $\mathrm{mg} / \mathrm{mL}$. Hasil yang didapat berupa konsentrasi biliverdin yang kemudian dikonversi menjadi unit enzim (konsentrasi produk yang terbentuk per menit). Hasil tersebut menunjukkan bahwa fraksi amonium sulfat $45-65 \%$ memiliki aktivitas spesifik enzim yang terbesar, yaitu senilai 0.0158 unit/mg dibandingkan fraksi 65$85 \%$ yang hanya senilai 0.0069 unit/mg (Tabel 2).

Tabel 1 Bobot Protein Hasil Fraksinasi Amonium Sulfat

\begin{tabular}{lll}
\hline No & Fraksi & Bobot protein (gram) \\
\hline 1 & $45-65 \%$ & 0.3788 \\
2 & $65-85 \%$ & 0.1874 \\
\hline
\end{tabular}

Tabel 2 Aktivitas Enzim Heme Oksigenase

\begin{tabular}{llllll}
\hline Sampel & $\begin{array}{l}\text { Kadar protein } \\
(\mathrm{mg} / \mathrm{mL})\end{array}$ & $\begin{array}{l}\text { [biliverdin] } \\
(\mathrm{mg} / \mathrm{mL})\end{array}$ & $\begin{array}{l}\text { Unit enzim } \\
(\mathrm{U})\end{array}$ & $\begin{array}{l}\text { Unit aktivitas } \\
(\mathrm{U} / \mathrm{mL})\end{array}$ & $\begin{array}{l}\text { Aktivitas spesifik } \\
(\mathrm{U} / \mathrm{mg})\end{array}$ \\
\hline Ekstrak kasar & 4.1912 & 0.0073 & 0.0015 & 0.0146 & 0.0034 \\
Fraksi $45-65 \%$ & 1.0725 & 0.0085 & 0.0017 & 0.0170 & 0.0158 \\
Fraksi 65-85\% & 0.9229 & 0.0032 & 0.0006 & 0.0064 & 0.0069 \\
\hline
\end{tabular}




\section{Kinetika Biosensor Heme Oksigenase Teramobil}

Parameter yang diukur pada pengukuran kinetika biosensor adalah kadar hemoglobin darah yang ditunjukkan oleh kuat arus yang terbaca pada potensiometer. Pengukuran kadar hemoglobin dilakukan dengan terlebih dahulu membuat kurva standar hemoglobin dengan menggunakan biosensor pada konsentrasi $0.05,0.10,0.15$, dan 0.20 $\mathrm{g} / \mathrm{dL}$. Arus listrik hasil pengukuran sampel darah kemudian dikonversi menjadi satuan kadar hemoglobin berdasarkan kurva standar hemoglobin (Gambar 2). Hasil pengukuran kadar hemoglobin dengan menggunakan Biosensor yang telah dibuat pada sampel A, B, dan $\mathrm{C}$ berturut-turut sebesar 12.0, 13.8, dan $14.3 \mathrm{~g} / \mathrm{dL}$, sedangkan hasil pengukuran dengan uji laboratorium standar berturut-turut sebesar 13.2, 13.4, dan 14.2 g/dL (Tabel 3). Presisi alat yang terhitung berdasarkan hasil pengukuran yaitu sebesar 0.8 , sedangkan tingkat akurasi alat adalah sebesar $96.04 \%$.

Tabel 3 Kadar Hemoglobin Dengan Uji Biosensor Dan Uji Laboratorium Standar

\begin{tabular}{lll}
\hline \multirow{2}{*}{ Sampel } & \multicolumn{2}{l}{ Kadar Hb rata-rata $(\mathrm{g} / \mathrm{dL})$} \\
\cline { 2 - 3 } & Uji biosensor & Uji laboratorium \\
\hline $\mathrm{A}$ & $12.0 \pm 1.62$ & $13.2 \pm 0.09$ \\
$\mathrm{~B}$ & $13.8 \pm 0.21$ & $13.4 \pm 0.16$ \\
$\mathrm{C}$ & $14.3 \pm 0.76$ & $14.2 \pm 0.12$ \\
\hline
\end{tabular}

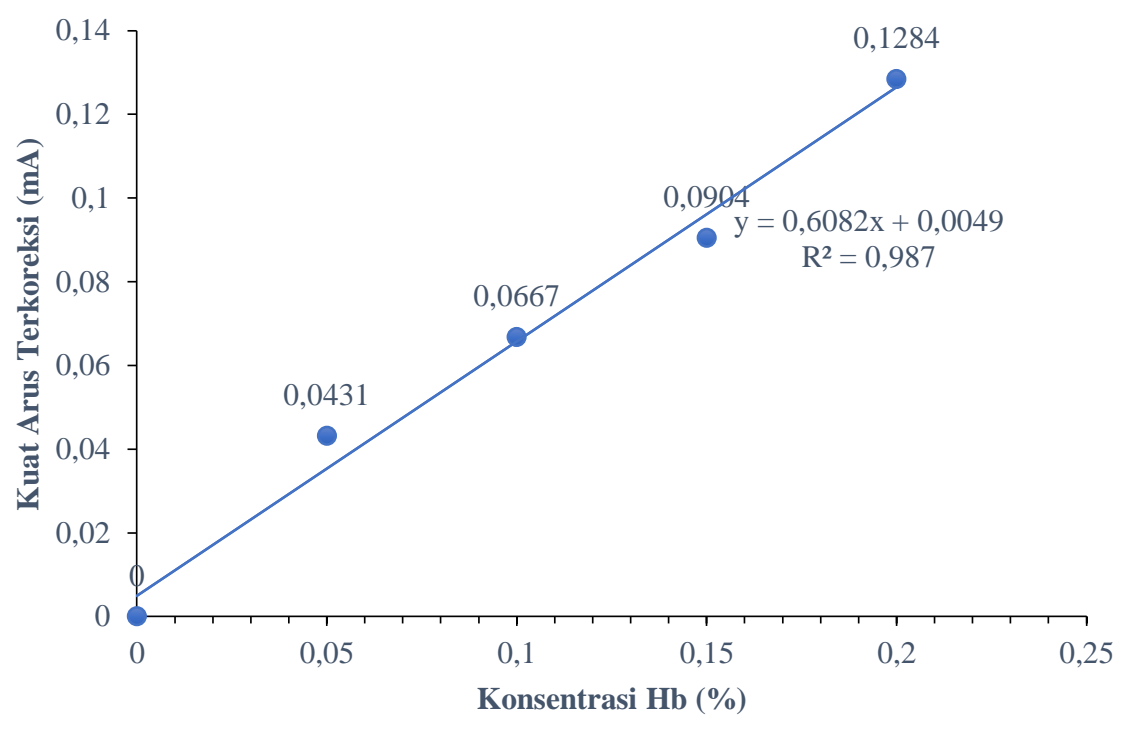

Gambar 2 Kurva standar hemoglobin

\section{PEMBAHASAN}

Berdasarkan kurva pertumbuhan yang didapat, waktu inkubasi kultur sel yang optimum adalah dimulai pada jam ke-18 karena kultur berada pada titik awal dari puncak jumlah biomassa selnya. Quinn et al. (2011) menyebutkan bahwa metabolit primer seperti asam amino, enzim, dan vitamin sangat dibutuhkan oleh mikroba dalam menunjang proses pertumbuhannya, sehingga metabolit tersebut diproduksi dalam jumlah besar pada saat fase pertumbuhan terjadi. Berdasarkan kurva pertumbuhan tersebut, waktu inkubasi kultur sel yang optimum adalah dimulai pada jam ke-18 karena kultur berada pada titik awal dari puncak jumlah biomassa selnya, sehingga 
jumlah heme oksigenase yang terdapat pada koloni bakteri berada pada puncaknya. Letoffe et al. (1994) juga menyebutkan bahwa heme oksigenase sangat dibutuhkan pada fase pertumbuhan bakteri untuk menghasilkan suplai zat besi yang dapat membantu proses pertumbuhan koloni bakteri.

Biomassa sel yang diperoleh dari kultivasi kultur bakteri dilisis dengan menggunakan teknik sonikasi dan sentrifugasi untuk mengisolasi enzim heme oksigenase yang terdapat di dalamnya. Penggunaan sonikator efektif dalam melisis sel bakteri. Sel bakteri yang telah hancur ditandai dengan berkurangnya viskositas suspensi yang dapat diamati secara kasat mata. Penggunaan teknik sentrifugasi dengan kecepatan lebih dari 21000 $g$ selain dapat membantu penghancuran sel, juga dapat memisahkan enzim heme oksigenase dari debris sel bakteri (Fang et al. 2012). Tahapan berikutnya setelah isolasi enzim adalah fraksinasi ekstrak kasar enzim. Fraksinasi heme oksigenase dilakukan dengan pengendapan bertingkat pada konsentrasi amonium sulfat $45-65 \%$ dan $65-85 \%$. Tahapan fraksinasi amonium sulfat dapat meningkatkan konsentrasi enzim dan kemurnian enzim. Hal tersebut berdampak pada aktivitas enzim yang lebih tinggi dibandingkan dengan ekstrak kasar sebelum dilakukan fraksinasi. Amonium sulfat digunakan pada proses fraksinasi karena sifatnya yang dapat membentuk kejenuhan bertingkat, sehingga dapat mengendapkan protein terlarut pada tingkat kejenuhan yang diinginkan. Berdasarkan Hammami et al. (2013), heme oksigenase dari Corynebacterium diphteriae dapat diisolasi pada tingkat kemurnian amonium sulfat sebesar 60-85\%. Hasil fraksi yang didapatkan akan digunakan dalam pengukuran kadar protein dan uji aktivitas enzim pada tahapan selanjutnya

Pengukuran kadar protein ekstrak kasar

enzim dari masing-masing fraksi amonium sulfat dan pengukuran aktivitas berfungsi untuk menghitung aktivitas spesifik enzim. Menurut Evtugyn (2014), enzim merupakan salah satu biomolekul jenis protein yang berfungsi sebagai biokatalis untuk reaksireaksi kimia. Pemurnian enzim berfungsi untuk meningkatkan aktivitas spesifik enzim. Aktivitas spesifik merupakan nilai rasio aktivitas enzim dengan bobot protein sampel. Aktivits enzim dapat diamati berdasarkan kenaikan konsentrasi biliverdin dalam sistem reaksi. Biliverdin merupakan produk hasil reaksi enzimatik dari heme oksigenase yang akan semakin cepat pembentukannya seiring dengan peningkatan jumlah enzim (Yanatori et al. 2019). Berdasarkan nilai aktivitas spesifik enzim yang didapatkan tersebut, fraksi amonium sulfat $45-65 \%$ akan digunakan dalam pembuatan biosensor pada tahapan selanjutnya.

Amobilisasi enzim pada permukaan lapisan karbon elektroda berfungsi agar enzim dapat bekerja menguraikan substrat yang menempel pada lapisan karbon (Kurniasih 2014). Parameter yang diukur pada pengukuran kinetika biosensor adalah kadar hemoglobin darah yang ditunjukkan oleh kuat arus yang terbaca pada potensiometer. Heme oksigenase yang teramobil akan memicu terjadinya reaksi enzimatik di permukaan elektroda. Menurut Yanatori et al. (2019), heme oksigenase dapat menimbulkan reaksi pengubahan heme menjadi molekul biliverdin. Pengubahan tersebut diiringi oleh terbentuknya ion $\mathrm{Fe}^{2+}$ atau $\mathrm{Fe}^{3+}$ serta elektron bebas sebagai hasil samping reaksi enzimatik. Terbentuknya elektron bebas tersebut dapat menciptakan aliran arus listrik apabila diukur dengan potensiometer (Yanatori et al. 2019). Berdasarkan prinsip tersebut, maka dapat diketahui bahwa peningkatan arus listrik yang terbaca akan selaras dengan kenaikan konsentrasi hemoglobin. Presisi alat yang terhitung berdasarkan hasil pengukuran yaitu sebesar 0.8, sedangkan tingkat akurasi alat adalah sebesar 96.04\%. Strambini et al. (2015) 
menyebutkan bahwa nilai akurasi di atas $95 \%$ termasuk dalam kategori baik, yang berarti hasil pengukuran alat cukup akurat dalam mengukur kadar hemoglobin darah.
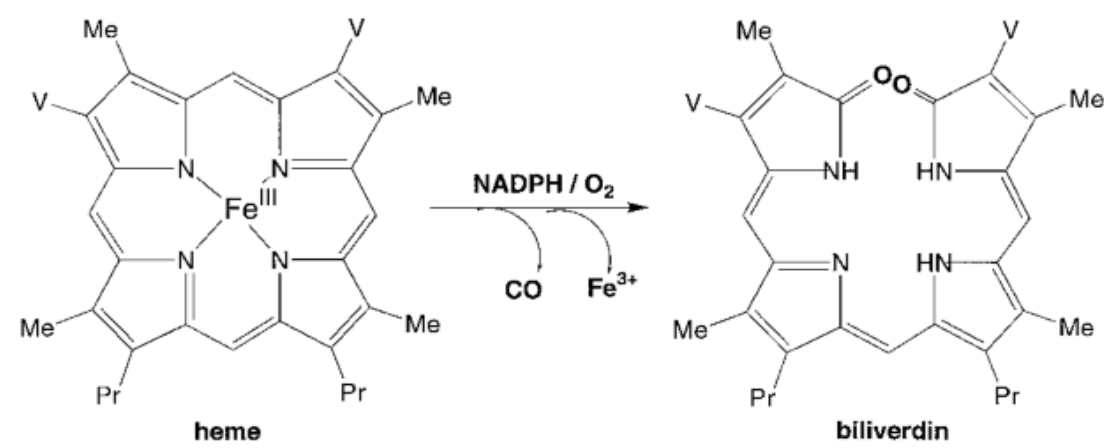

Gambar 3 Reaksi pembentukan biliverdin dari heme (Wilks dan Schmitt 1998)

\section{UCAPAN TERIMA KASIH}

Penulis menyampaikan terima kasih kepada Dirjen BELMAWA Kemenristekdikti yang telah mendanai penelitian ini dalam Program Kreativitas Mahasiswa (PKM) 2019. Penulis juga mengucapkan terima kasih kepada Ibu Dr. Suryani, SP, M.Sc selaku dosen pendamping yang telah memberikan dukungan selama penelitian ini berlangsung. Ucapan terima kasih juga penulis sampaikan kepada PKM Center IPB, Direktorat Kemahasiswaan dan Pengembangan Karir IPB, serta semua pihak yang terlibat dalam penyelesaian dan keberhasilan penelitian ini.

\section{DAFTAR PUSTAKA}

Cheng Y, Wei H, Sun R, Tian Z, Zheng X. 2016. Rapid method for protein quantitation by Bradford assay after elimination of the interference of polysorbate 80. Anal. Biochem. 494:3739.

Colak O, Arslan H, Zengin H, Zengin G. 2012. Amperometric detection of glucose by polyaniline-activated carbon composite carbon paste electrode. Int. J. Elect. Sci. 7:6988-6997.

Evtugyn G. 2014. Biosensors: Essentials. Berlin (DE): Springer-Verlag.
Fang J, Qin H, Nakamura H, Tsukigawa K, Shin T, Maeda H. 2012. Carbon monoxide, generated by heme oxygenase- 1 , mediates the enhanced permeability and retention effect in solid tumors. Cancer. Sci. 103(3):535-541.

Hammami I, Siala R, Jridi M, Ktari N, Nasri M, Tiki MA. 2013. Partial purification and characterization of chilO8, a novel antifungal chitinase produced by Bacillus cereus IO8. J Applied Microbiol. 115:358-366.

Karama M, Johnson RP, Holtslander R, Gyles CL. 2008. Phenotypic and genotypic characterization of verotoxinproducing Eschericia coli O103:H2 isolates from cattle and humans. $J$. Clinical. Microbiol. 46(11):35693575 .

Katanga J, Mgongo M, Hashim T, StrayPedersen B, Msuya SE. 2015. Screening for syphilis, HIV, and hemoglobin during pregnancy in moshi municipality, tanzania: how is the health system performing [komunikasi singkat]. Sci. J. Pub. Health. 3(1):93-96.

Kurniasih R. 2014. Glukosa oksidase teramobil glutaraldehida pada 
elektroda pasta karbon termodifikasi nanoserat polianilin sebagai biosensor glukosa [skripsi]. Bogor (ID): Institut Pertanian Bogor.

Quinn PJ, Markey BK, Leonard FC, FitzPatrick ES, Fanning S, Hartigan PJ. 2011. Veterinary Microbiology and Microbial Disease. Oxford (UK): Wiley-Blackwell.

Rodak BF, Fritsma GA, Keohane EM. 2012. Hematology: Clinical Principles and Applications. Missouri (US): Elsevier Inc.

Strambini LM, Longo A, Scarano S, Prescimone T, Palchetti I, Minunni M, Giannessi D, Barillaro G. 2015. Self-powered microneedle-based biosensors for pain-free highaccuracy measurement of glycaemia in interstitial fluid. Biosensors and Bioelectronics. 66:162-168.

Wilks, A dan Schmitt, MP. 1998. Expression and characterization of a heme oxygenase (HmuO) from Corynebacterium diphtheriae. The $J$ of Biol Chem. 273(2):837-841.

Yanatori I, Richardson DR, Toyokuni S, Kishi F. 2019. How iron is handled in the course of heme catabolism: integration of heme oxygenase with intracellular iron transport mechanisms mediated by poly (rC)binding protein-2. Arch. Biochem. Biophys. 672:1-8. 